\title{
Infected ptosis surgery - a rare complication from a multidrug-resistant organism
}

\author{
This article was published in the following Dove Press journal: \\ Clinical Ophthalmology \\ 17 April 2015 \\ Number of times this article has been viewed
}

\author{
Chan Jan-Bond ${ }^{1,2}$ \\ Abdul-Rahman Norazah' \\ Palani Sree-Kumar' \\ Embong Zunaina ${ }^{2}$ \\ Qamarruddin Fazilawati' \\ 'Department of Ophthalmology, \\ Hospital Selayang, Lebuhraya \\ Selayang-Kepong, Batu Caves, \\ Selangor, Malaysia; ${ }^{2}$ Department \\ of Ophthalmology, School of Medical \\ Sciences, Universiti Sains Malaysia, \\ Kubang Kerian, Kelantan, Malaysia
}

\begin{abstract}
A 7-year-old boy had a case of congenital ptosis of the right eye and has undergone frontalis sling surgery using Gore-tex material. There was no intraoperative or immediate postoperative complication. However, the patient defaulted his follow-up and presented with right eye preseptal abscess secondary to infected surgical wound 1 month after surgery. He was treated with multiple antibiotics and underwent repeated incision and drainage procedures. However, there was still no resolution of the right eye preseptal abscess. The patient's condition subsequently improved after removal of the Gore-tex material and treatment with an antibiotic combination of ceftazidime and amikacin. Microbiological analysis finally isolated the multidrug resistant Acinetobacter species. At 6 months follow-up, his right upper eyelid was healed with scarring, but without ptosis.
\end{abstract}

Keywords: frontalis sling, infected wound, Gore-tex material, expanded polytetrafluoroethylene

\section{Introduction}

Congenital ptosis is an abnormally low position of the upper eyelid in relation to the globe, which occurs either at birth or soon after. The indication for surgery is usually amblyopia or ocular torticollis. There are several methods of ptosis surgery, including levator muscle resection, frontalis suspension procedure, Fasanella-Servat procedure, and Müller muscle-conjunctival resection. ${ }^{1,2}$ One of the most popular methods of ptosis surgery is the frontalis suspension procedure. There are various materials available to secure the lids to the frontalis muscles in the frontalis suspension procedure, including polypropylene suture, nylon suture, silicone, mersilene mesh, and Gore-tex material. ${ }^{3}$ We are reporting a rare case of infected Gore-tex material that was used in modified frontalis sling surgery for congenital ptosis.

\section{Case report}

A 7-year-old Chinese boy with no known medical history, presented with history of right eye ptosis since he was 10 months old. He was diagnosed with right-eye congenital ptosis. He had a marginal reflex distance of $1 \mathrm{~mm}$, with levator function of 3 $\mathrm{mm}$ in the right eye. The marginal reflex distance of the left eye was $2 \mathrm{~mm}$, with $7 \mathrm{~mm}$ levator function. There was absence of upper lid crease on both eyes. He underwent ptosis surgery on the right eye as he developed mild amblyopia in the right eye, with the best-corrected vision of $6 / 12$.

A right eye frontalis sling procedure with modified Fox's pentagon $\operatorname{method}^{4}$ was done using Gore-tex material in Selayang Hospital, Malaysia. There was no intraoperative or immediate postoperative complication. Chloramphenicol ointment was applied 8-hourly to the surgical wound site on the right upper eyelid. The patient was discharged on day 1 postoperation, with plan to review after 1 week. Chloramphenicol ointment was given to the patient till review.
Correspondence: Chan Jan-Bond Department of Ophthalmology, School of Medical Sciences, Universiti Sains Malaysia, 16150 Kubang Kerian, Kelantan, Malaysia

Tel +60122068126

Fax +609765 3370

Email janbond@hotmail.com 


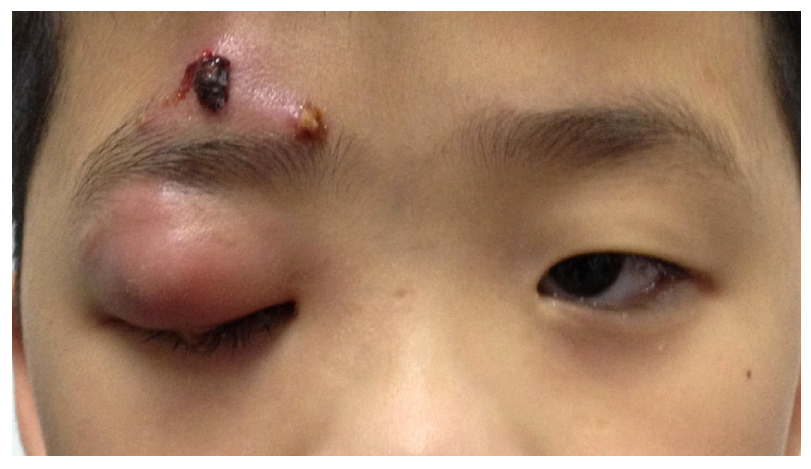

Figure I Right upper eyelid swelling causing complete ptosis with crusted pus at the surgical wound site.

However, he defaulted his follow-up and only came back 1 month after surgery. He had used his medication for only 1 week and had stopped thereafter. At this presentation, he complained of painful swelling (of 7 days duration) of the right upper eyelid. The right upper eyelid swelling was associated with pus discharge from the surgical wound site. The vision in the right eye was not getting worse.

On examination, the patient was generally alert, conscious, and afebrile. His best-corrected visual acuity was $6 / 12$ in the right eye and 6/9 in the left eye. His right upper eyelid was swollen causing complete ptosis with an area of redness. There was presence of crusted pus at the surgical wound site (Figure 1). The extraocular movements were full on all gazes. The conjunctiva was white with no chemosis. Anterior segment and fundus examination were unremarkable. A diagnosis of right eye preseptal abscess secondary to the infected surgical wound was made.

The patient was admitted and treated with intravenous co-amoxiclav $800 \mathrm{mg}$ ( $25 \mathrm{mg} / \mathrm{kg})$ 8-hourly for a duration of 1 week. Chloramphenicol ointment was applied 8-hourly to the infected surgical wounds, together with instillation of topical chloramphenicol eye drops 6-hourly to the right eye. An emergency incision and drainage of the right upper eyelid was performed, and about $5 \mathrm{~mL}$ of pus was drained out.

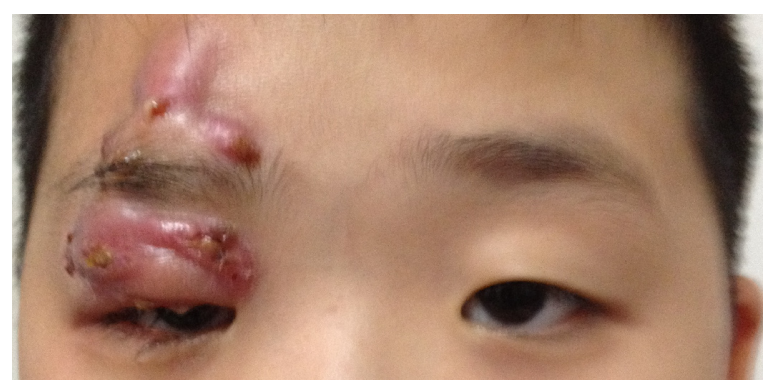

Figure 2 Right upper eyelid still swollen and inflamed with partial mechanical ptosis at I week post-incision and drainage procedure.

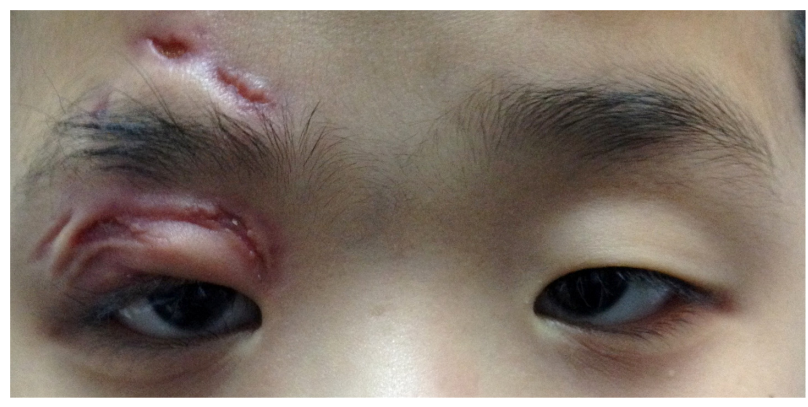

Figure 3 Right upper eyelid healed with scarring but without ptosis at 3 months post-removal of Gore-tex material.

A swab of the purulent discharge was sent for culture and sensitivity. However, the culture did not yield any growth. At 1 week post-incision and drainage, the right upper eyelid was still inflamed and swollen with partial mechanical ptosis (Figure 2).

In view of no improvement in the healing process, the antibiotic was changed to intravenous cefotaxime $750 \mathrm{mg}$ $(25 \mathrm{mg} / \mathrm{kg}$ ) 8-hourly for a duration of 1 week. The topical antibiotic eye drop was also changed to topical moxifloxacin 6-hourly for the right eye. The patient was subjected to a second incision and drainage. However, there was still no improvement; hence an antibiotic combination of intravenous ceftazidime $750 \mathrm{mg}$ ( $25 \mathrm{mg} / \mathrm{kg})$ 8-hourly for 5 days and intravenous amikacin $210 \mathrm{mg}(15 \mathrm{mg} / \mathrm{kg}) 12$-hourly for 3 days was commenced. A third incision and drainage was performed together with removal of the Gore-tex material. A culture from the final pus sample isolated multidrugresistant Acinetobacter species, which was resistant to all penicillins, cephalosporins, carbapenems, fluoroquinolones, and aminoglycosides. His condition subsequently improved. There was resolution of the right upper eyelid swelling, with no more pus discharge. The patient was discharged, with chloramphenicol ointment to apply to the surgical wound 8 -hourly for 2 weeks.

After 6 months follow-up (about 3 months post-removal of Gore-tex material), the patient's right upper eyelid was healed with scarring, but without ptosis (Figure 3 ). The healed ptosis is most likely due to scarring caused by the infection. His right eye best-corrected visual acuity was 6/9.

\section{Discussion}

Frontalis suspension surgery is a commonly used surgery in cases of congenital ptosis with poor levator function, chronic progressive ophthalmoplegia (CPEO), muscular dystrophy, third nerve palsy, myasthenia gravis, and aponeurotic ptosis in elderly patients. ${ }^{1,3}$ There are several suspension materials 
that can be used in frontalis suspension surgery. Autologous graft materials include autogenic or allogenic fascia lata. Synthetic materials such as polypropylene suture, nylon suture, silicone, mersilene mesh, and Gore-tex can also be used. ${ }^{5}$

Gore-tex material or expanded polytetrafluoroethylene (ePTFE) is suitable for suspension surgery because it is less bulky and less stretchable. ${ }^{5}$ It is a nontoxic polymer used in various other implantable medical products, including vascular grafts and hernia repair patches. Unlike other implantable materials, ePTFE is biocompatible. Micropores within the material are too small to allow infiltration of fibrovascular tissues hence allowing for easier removal or manipulation to adjust the eyelid height. ${ }^{6,7}$

However, its porous nature may allow proliferation of bacterial contaminants and cause abscess formation, resulting in a high risk of soft tissue complications. In our patient, constant scratching may have led to infection of the wound. With tracking of the long, porous ePTFE material through an open wound, it serves as a good site for bacterial proliferation.

The periorbital abscess was chronic and persistent even after treatment with multiple antibiotics and repeated incision and drainage, indicating the highly virulent nature of the causative organism. This could be due to the formation of biofilm by the causative bacteria, especially on biomedical implants, causing antimicrobial resistance. ${ }^{8}$ Complete resolution in our case occurred only after removal of the Gore-tex material, which might have harbored the virulent microorganism.

There were a few other reports of complications of ptosis surgery such as granuloma and infection..$^{2,3,9}$ In a retrospective study of 59 frontalis suspension procedures, infection with preseptal cellulitis appeared in one case $(1.7 \%)$ and required removal of the material, and in two cases $(3.4 \%)$ there were foreign body granulomas that were resolved by excision. ${ }^{10}$ There were other reports of post-ptosis surgery complicated by long-standing postoperative infection which were mostly associated with mycobacterium or candida infection. ${ }^{11,12}$ However, to our knowledge, there was no reported case of long-standing post-ptosis surgery infection involving multidrug-resistant Acinetobacter species. Acinetobacter rarely colonizes implant materials; ${ }^{13}$ it commonly causes nosocomial infections such as pneumonia, urinary tract infection, and skin infections. ${ }^{14,15}$

In a delayed and long-standing post-frontalis surgery infection, multidrug-resistant organisms may be responsible for delayed healing and poor response to treatment. Surgical removal of infected slings and a prolonged course of antibiotics may be required for complete resolution.

\section{Acknowledgment}

We would like to thank our patient and his parents who have given their informed consent for the publication of his photo.

\section{Disclosure}

The authors report no conflicts of interest in this work.

\section{References}

1. Baroody M, Holds JB, Vick VL. Advances in the diagnosis and treatment of ptosis. Curr Opin Ophthalmol. 2005;16(6):351-355.

2. Ben-Simon GJ, Macedo AA, Schwarcz RM, Wang DY, McCann JD, Goldberg RA. Frontalis suspension for upper eyelid ptosis: evaluation of different surgical designs and suture material. Am J Ophthalmol. 2005; 140(5):877-885.

3. Wasserman BN, Sprunger DT, Helveston EM. Comparison of materials used in frontalis suspension. Arch Ophthalmol. 2001;119(5): 687-691.

4. Hafez A, Mahmoud MS. Mersilene mesh brow suspension: a new modified Fox's procedure - five years clinical experience. Middle East Afr J Ophthalmol. 2008;15(3):117-122.

5. Takahashi Y, Leibovitch I, Kakizaki H. Frontalis suspension surgery in upper eyelid blepharoptosis. Open Ophthalmol J. 2010;4:91-97.

6. Zweep HP, Spauwen PH. Evaluation of expanded polytetrafluoroethylene (e-PTFE) and autogenous fascia lata in frontalis suspension. A comparative clinical study. Acta Chir Plast. 1992;34(3):129-137.

7. Bajaj MS, Sastry SS, Ghose S, Betharia SM, Pushker N. Evaluation of polytetrafluoroethylene suture for frontalis suspension as compared to polybutylate-coated braided polyester. Clin Experiment Ophthalmol. 2004;32(4):415-419.

8. Dunne WM Jr. Bacterial adhesion: seen any good biofilms lately? Clin Microbiol Rev. 2002;15(2):155-166.

9. Mehta P, Patel P, Olver JM. Functional results and complications of Mersilene mesh use for frontalis suspension ptosis surgery. $\mathrm{Br}$ J Ophthalmol. 2004;88(3):361-364.

10. Mencia-Gutierrez E, Clariana-Martin A, Gutierrez-Diaz E, MonsalveCordova J, Izquierdo-Rodriguez C. Resultados y complicaciones del politetrafluoroetileno expandido [Results and complications of expanded polytetrafluoroethylene in frontalis suspension ptosis surgery. Study of 59 cases]. Arch Soc Esp Oftalmol. 2005;80(8):443-448. Spanish.

11. Davies BW, Bratton EM, Durairaj VD, Hink EM. Bilateral Candida and atypical mycobacterial infection after frontalis sling suspension with silicone rod to correct congenital ptosis. Ophthalmic Plast Reconstr Surg. 2013;29(4):e111-e113.

12. Walang B, Rath S, Sharma S. Nontuberculous mycobacterial infection after frontalis sling surgery using silicone rod. J Ophthalmic Inflamm Infect. 2012;2(4):219-221.

13. Go J, Cunha BA. Acinetobacter baumannii: infection control implications. Infect Dis Pract. 1999;23:65-68.

14. Bergogne-Berezin E, Towner KJ. Acinetobacter spp. as nosocomial pathogens: microbiological, clinical, and epidemiological features. Clin Microbiol Rev. 1996;9(2):148-165.

15. Falagas ME, Koletsi PK, Bliziotis IA. The diversity of definitions of multidrug-resistant (MDR) and pandrug-resistant (PDR) Acinetobacter baumannii and Pseudomonas aeruginosa. J Med Microbiol. 2006; 55(Pt 12):1619-1629. 


\section{Publish your work in this journal}

Clinical Ophthalmology is an international, peer-reviewed journal covering all subspecialties within ophthalmology. Key topics include: Optometry; Visual science; Pharmacology and drug therapy in eye diseases; Basic Sciences; Primary and Secondary eye care; Patient Safety and Quality of Care Improvements. This journal is indexed on

Submit your manuscript here: http://www.dovepress.com/clinical-ophthalmology-journal
PubMed Central and CAS, and is the official journal of The Society of Clinical Ophthalmology (SCO). The manuscript management system is completely online and includes a very quick and fair peer-review system, which is all easy to use. Visit http://www.dovepress.com/ testimonials.php to read real quotes from published authors. 